\title{
Modes of Use of the Palm Borassus aethiopum Mart. by the Rural Populations of Eastern and Central-Eastern Regions from Burkina Faso
}

\author{
Oumarou Zongo, François Tapsoba, Hama Cisse, Yves Traore and Aly Savadogo*
}

LABIA/CRSBAN/Department of Biochemistry and Microbiology, UFR-SVT, University of

Ouagal Pr Joseph KI-ZERBO, Burkina Faso, 03 BP 7021 Ouagadougou, Burkina Faso

*Corresponding author

\begin{tabular}{|c|}
\hline Keywords \\
\hline $\begin{array}{l}\text { Modes of use; Borassus } \\
\text { aethiopum Mart.; Eastern } \\
\text { and Central Eastern } \\
\text { Region; Burkina }\end{array}$ \\
\hline Article Info \\
\hline $\begin{array}{l}\text { Accepted: } \\
0 \text { November } 2018 \\
\text { Available Online: } \\
10 \text { December } 2018\end{array}$ \\
\hline
\end{tabular}

\section{A B S T R A C T}

The eastern and central-eastern regions of Burkina are home to important natural stands of palmyra palm Borassus aethiopum Mart. The objective of this study was to determine the different modes of use of palm Borassus aethiopum Mart. by rural populations in the eastern and central-eastern regions of Burkina. Surveys in the form of questionnaires as well as interviews with structures and resource persons were conducted in three villages in each region with palm stands. A total of 300 people including 150 in the eastern region and 150 in the central-eastern region were interviewed. The results show that all parts of the palmyra Borassus aethiopum Mart. are exploited by rural populations. Sixty $(60 \%)$ of the people surveyed use the fruits, $9 \%$ leaves and $5 \%$ the stems. The main forms of farming are the pulling out of seedlings, the collection of ripe fruits to produce seedlings called koboula (in the local yaana language) for consumption or sale and the cutting of the wood (stem) and leaves that come into the construction of houses, sheds, fences, etc. The exploitation of the sap as a drink as well as the many possibilities of use in basketry offered by the palm leaves are unknown. Seedling production is the main income generating activity for the population. It is therefore necessary to consider other forms of exploitation such as the production of wine from the sap as what is practiced in a sustainable way by the people of western region of Burkina.

\section{Introduction}

Sub-Saharan Africa is home to large stands of palmyra palms, particularly in the West African subregion, such as Senegal, Mali, Niger, Côte d'Ivoire and Burkina Faso (AkéAssi et Guinko, 1996). Previous studies have reported the existence of palmyra palm stands in Burkina Faso. These are western stands consisting mainly of the Borassus akeassii species whose fruits are green at maturity and those of Borassus aethiopum in the east with yellow fruits (Guinko, 1984; Ouédraogo et al., 2002; Bayton and Ouédraogo, 2009).

All parts of the palmyra palm are used in food, crafts, pharmacopoeia, fodder, energy, soil fertilization, construction, agroforestry, etc. Trade in products of this species is a socioeconomic activity in the areas where it is exploited (Yaméogo et al., 2008). In the western part of the country, the main forms of exploitation of the green type palm (Borassus 
akeassii) are sap extraction (Tapsoba et al., 2014), which is done using a sustainable technique that keeps the foot alive and always exploitable and cutting leaves for the making of furniture (chairs, mats, etc.) and other handicrafts (baskets, vans, bags, etc.) (Guinko and Ouédraogo, 2005; Yaméogo et al., 2008). They showed the importance of the palm in this part of the country where the sap or bandji (local drink) involved in the reinforcement of the social links through the happy and unhappy events (marriage, baptism, work of mutual assistance, funeral, etc.) and improved their living conditions. In addition, the sale of bandji and other handicraft palm products is an important source of income for players in this sector (Yaméogo et al., 2008; Ouoba et al., 2012, Tapsoba et al., 2014).

In the west, the palm has a domestic status and is rationally exploited and maintained by the people who make it a source of considerable financial income (Guinko and Ouédraogo, 2005). The palm stands of the East and the Center-East of the country which are just as important as those of the West, were long ignored by the Botanists who drew up the distribution cards of the palmyra palm in West Africa (Cabannes et al., 1987; Ouédraogo, 1999). In this eastern part of the country, the palm (Borassus aethiopum Mart.) grows wild and gives stands in several localities of central-eastern and eastern. The stands extend to Benin, Niger and Togo following the banks of the Pendjari River and its tributaries (Guinko and Ouédraogo, 2005). Until the 1980s, the palmyra palm did not always have regard in the exploitation of its products (Guinko, 1984). In order to find conservation strategies and new forms of valorization of palm stands in this region, knowledge of the different uses is necessary.

The purpose of this study is to identify the various known uses of the palm Borassus aethiopum Mart by local people in the Eastern and Central-Eastern region of Burkina Faso.

\section{Materials and Methods}

\section{Study area}

This study was carried out in the eastern regions (12 ${ }^{\circ} 03^{\prime}$ 00"North; O ${ }^{\circ} 22^{\prime}$ 00" East) and Central East (11 ${ }^{\circ} 47^{\prime} 21^{\prime \prime}$ North; $\mathrm{O}^{\circ} 21^{\prime}$ 25" West) from Burkina Faso where the natural stands of Borassus aethiopum Mart. meet (Figure 1 and 2). In the Eastern Region, three localities or villages (Kompienbiga, Kaboanga 1 and Kaboanga 2) located in the province of Kompienga ( $11^{\circ} 25^{\prime} 0^{\prime \prime}$ North; $0^{\circ}$ $55^{\prime} 0 "$ East) served as study sites. In the Center-East, these are the localities of Soudougui, Kamsé and Wango located in the province of Koulpélogo ( $11^{\circ} 25^{\prime} 0^{\prime \prime N o r t h ; ~} 0^{\circ}$ 10' 0" East).

\section{Choice of survey sites}

The choice of survey locations (provinces and villages) was carried out following a presurvey which consisted of an exploration in the various provinces of the Central-East and Central regions. This exploration was aimed, among other things, at identifying the localities near the stands, the relative abundance of the palms in each of the provinces in which the populations give an interest in the exploitation of Borassus aethiopum. The provinces of Kompienga (East) and Koulpélogo (Center-East) have been selected.

\section{Realisation of surveys}

The survey was conducted on the basis of a questionnaire on the use of palm known to the population and concerned 300 individuals in six localities (Table 2). The questionnaire focused mainly on the exploitation of the palm, the various parts used, the modes of use, the knowledge of palm wine and the knowledge of the technique of collection of the sap. Interviews with structures such as the Provincial Directorate of the Environment of 
Kompienga and Koulpélogo, the forest station of Soudougui and Kompienbiga and resource persons (elders, village chiefs) were also conducted in order to gather as much information as possible. Table 1 below presents the various possibilities of use of the palmyra palm known throughout the world.

\section{Data processing}

The SPHINX V5 software was used for the survey questionnaire. The survey data was analyzed with the IBM SPSS Statistics 20 software. The descriptive statistics of the various parameters made it possible to establish the tables and graphs. The Pearson correlation test verified significant correlations between survey parameters. The correlation is significant at the 0.05 level.

\section{Results and Discussion}

\section{Characteristics of the interviewed people}

The populations of the rural areas near the palm stands submitted to the questionnaires consist of women (45\%) and men (55\%) whose age is between 10 and 110 (Table 3). Individuals surveyed in the eastern and central-eastern regions are divided into eight ethnic groups and the majority of whom are the yaana, gourmantché, mossi and zhaoussé (Figure 3 and 4).

\section{Exploitation of the products of the palm Borassus aethiopum Mart.}

The results of the surveys showed that palm is exploited by all age groups of the local populations of the East and Center-East (74\% of the respondents). It is more exploited in the Koulpélogo province $(91 \%)$ than in the kompienga province $(58 \%)$. The farmers are composed of young people and adults (mostly women), $85 \%$ of whom have an age between 10 and 50. Among those who do not exploit the farm (26\% of respondents), the $90 \%$ have an age between 65 and 110 and are elderly or immigrants for the most part.

\section{Parts of Borassus aethiopum Mart. exploited by the populations}

The different parts of the palm are exploited by the interviewed people. Multipurpose tree mainly fruits, leaves and stems are used (Table 4). The rip fruits are consumed or used for the production of seedlings for consumption or marketing. The leaves are used to make handicrafts and to build fences or cattle pens. The stem enters the construction of hangars and houses (Table 5). In Koulpélogo province, $78 \%$ of respondents use fruit against $43 \%$ in Kompienga province. The leaves $(9 \%)$ and the stem (5\%) are poorly exploited in its areas. Sap is not exploited by rural populations in Eastern and Central East. Most individuals surveyed $(99 \%)$ ignore this form of exploitation of palm. The technique of sap collection is unknown. The analysis in Table 4 shows that the species is under exploited by the populations of the East and Central-East with regard to the different uses mentioned in Table 1 . In fact, $26 \%$ of the people surveyed do not use the palmyra and only fruits are the most used $(60 \%)$ among the different parts. The leaves and stems are weakly exploited by the population.

Other uses of Borassus aethiopum Mart. known by the rural populations

The ripe fruits (sweet juice) are also used in the preparation of certain food such as beans, millet or maize. The leaves are also used to cover the huts and attics. The male inflorescences and roots of Borassus aethiopum are used in the pharmacopoeia. Dried mesocarps from fruit are used as firewood. The flowers or male inflorescences gives a good potash and are used in pharmacopoeia. In addition, boiled seedlings 
called "Koboula" (Figure 7) in the local yaana language can be dried and processed into flour to make porridge, dough or couscous. This mode of transformation of seedlings allows a longer relative conservation, but little known and practiced by the rural population. The hypocotyls or seedlings of palm are also used in the pharmacopoeia to treat stomach ache, constipation, fever, etc. Hypocotyls are also used as a stimulant and aphrodisiac.

\section{Actual form of valorization of palmyra Borassus aethiopum Mart. in the East and Central-East}

In the eastern and central-eastern regions, the main uses of the palm are mainly for stems, fruits, leaves and seedlings. The exploitation of hypocotyls or young seedlings from ripe fruits (Fig. 5) remains the most widespread and is practiced by women and children in particular. Then we have the use of stems (wood) in the form of rafters for marketing (Figure 8). The leaves are little or not valued.
The seedlings are eaten raw, boiled or scratched and are highly appreciated by the people. According to the people surveyed, some of the ripe seedlings produced come into the family's diet and the rest are destined for sale and directed to the main towns in the region and even beyond the country (Benin and Togo). Most (96\%) of those surveyed consume seedlings. There are two techniques for producing palm seedlings (traditional on the ground and improved in a pit). In the traditional technique (Figure 6) the fruits are collected and placed on the ground at the beginning of wintering (May-June), the peduncles turned upwards then are covered with earth. The palm young seedlings are unearthed six to seven months later. For the improved or modern technique the production of seedlings is done in a pit or sprouter. The pit is first filled with a mixture of sand and earth and then, the fruits are arranged as in the so-called traditional technique and covered with earth.

Fig.1 Female palmyra of Borassus aethiopum Mart. in Kaboanga (East)

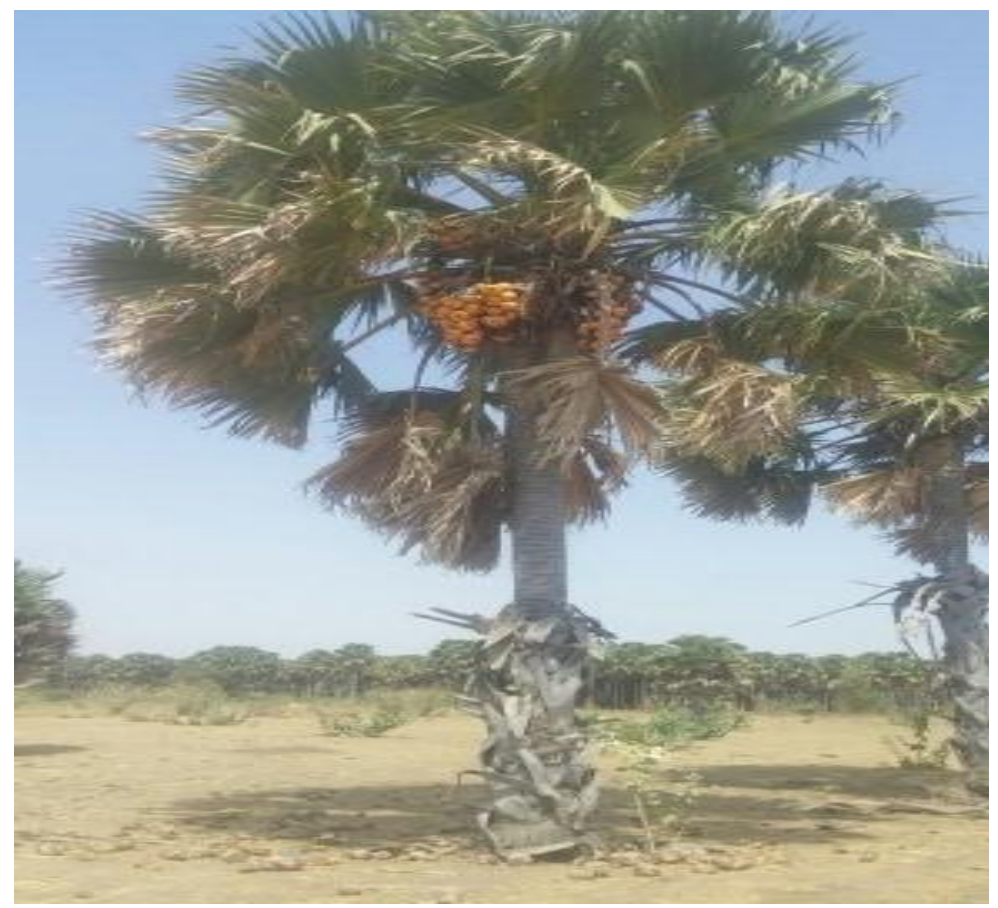


Fig.2 Dense palm stands of Borassus aethiopum Mart. in Wango (Central-East)

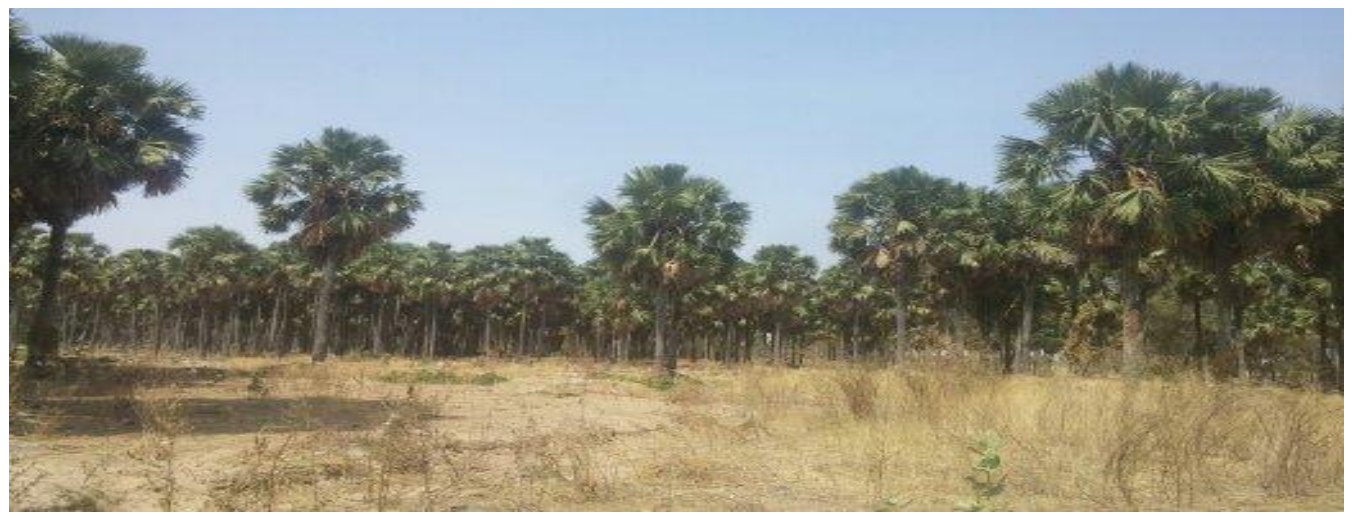

Fig.3 Distribution by ethnic group of the individuals surveyed in the East

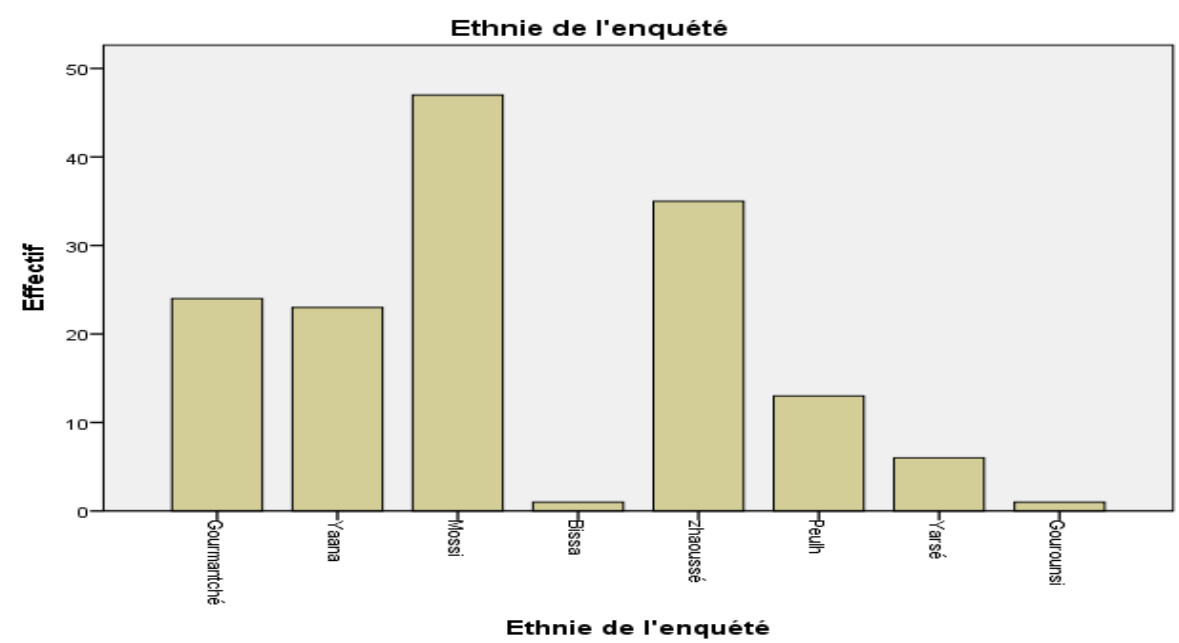

Fig.4 Distribution by ethnic group of individuals surveyed in central east

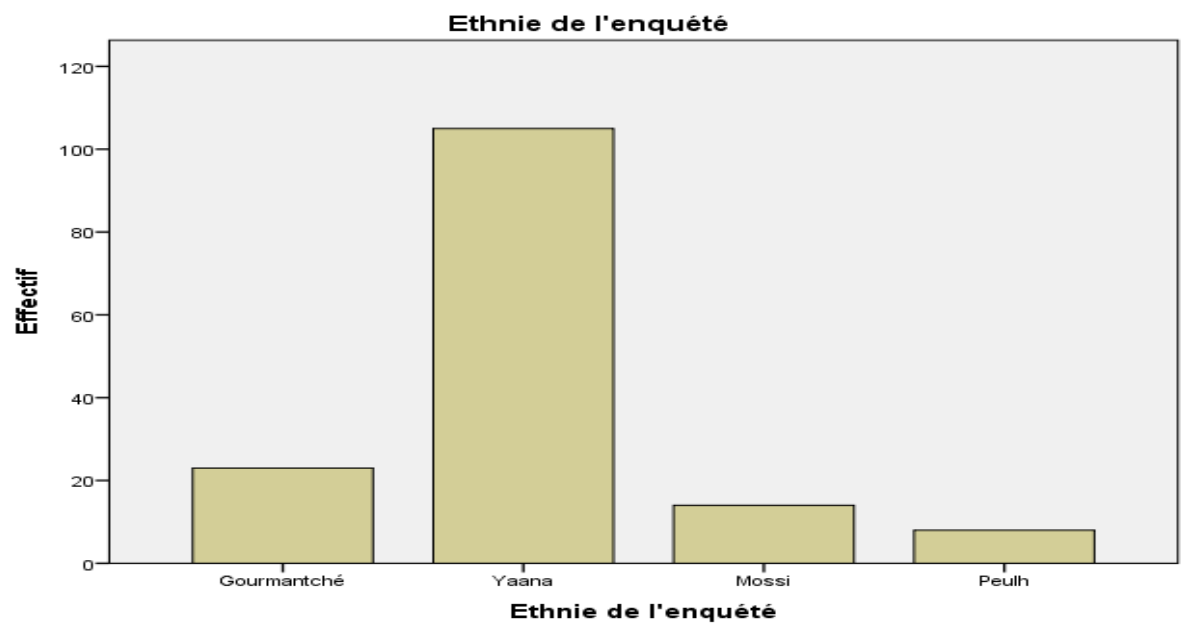


Fig.5 Exploitation of the different parts of the palmyra palm at Center-Est

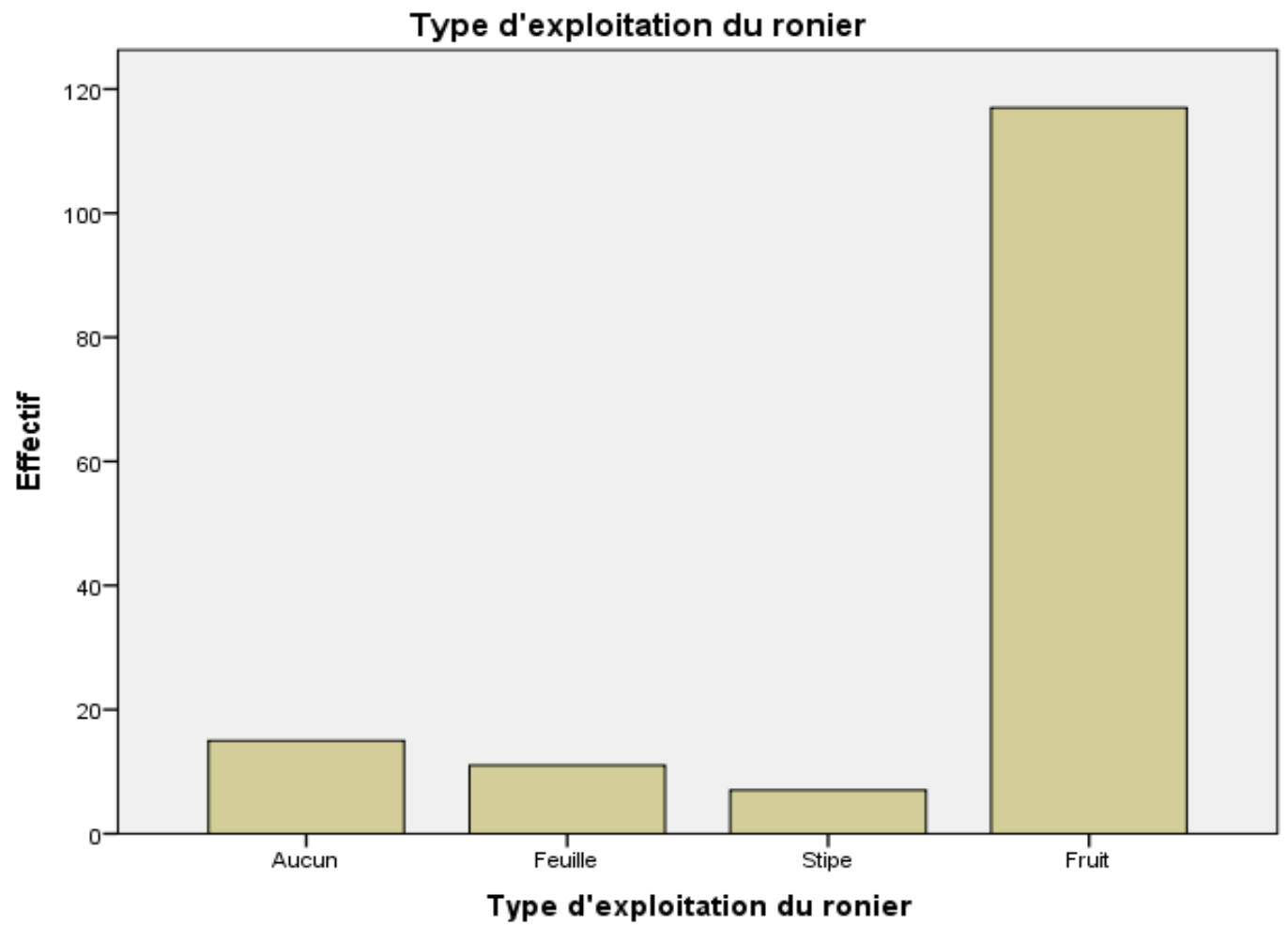

Fig.6 Traditional production of seedlings under palm stands in Wango

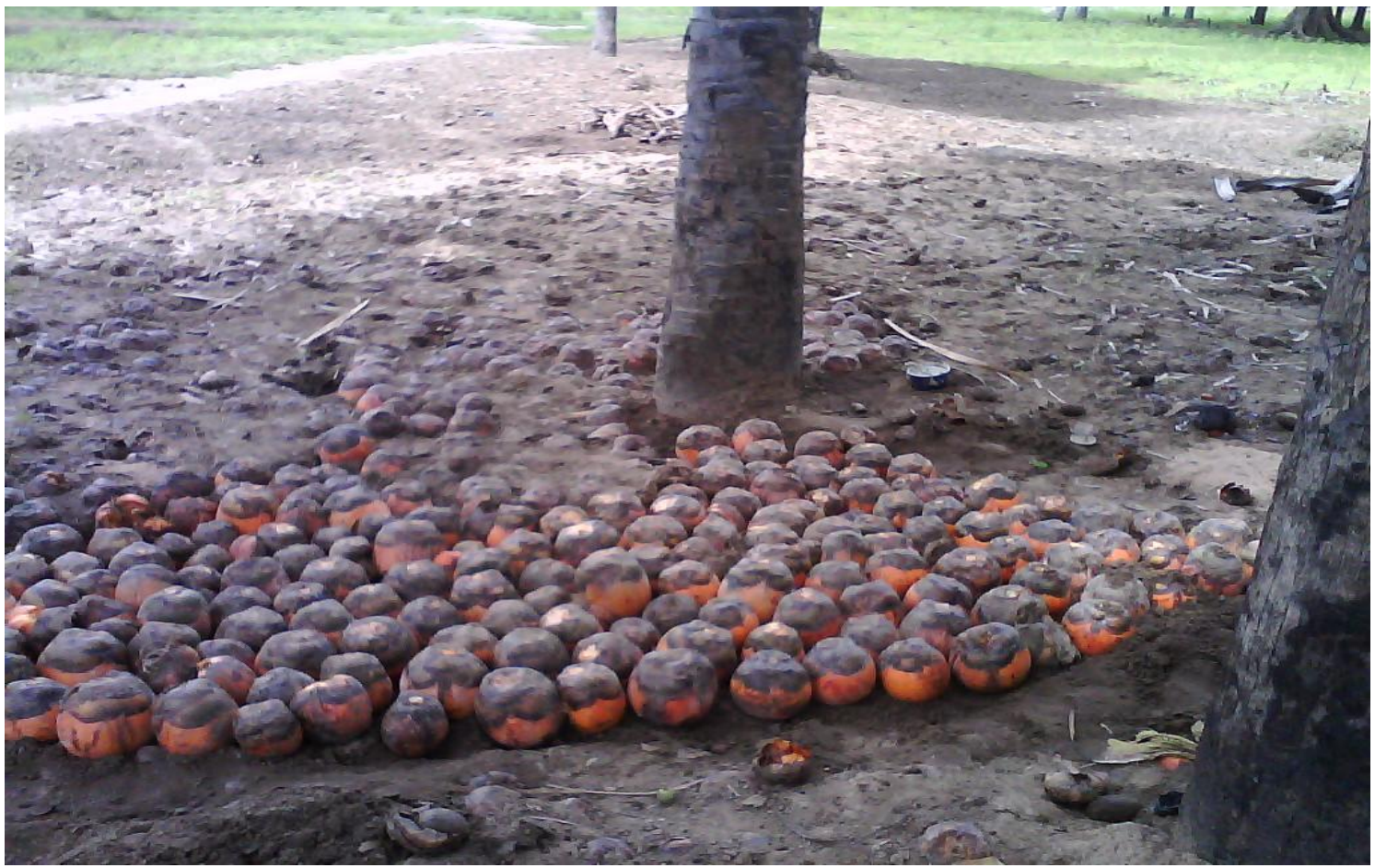


Fig.7 Boiled or hypocotyls seedlings of Borassus aethiopum Mart. sold at the Crossroads of kaboanga 1

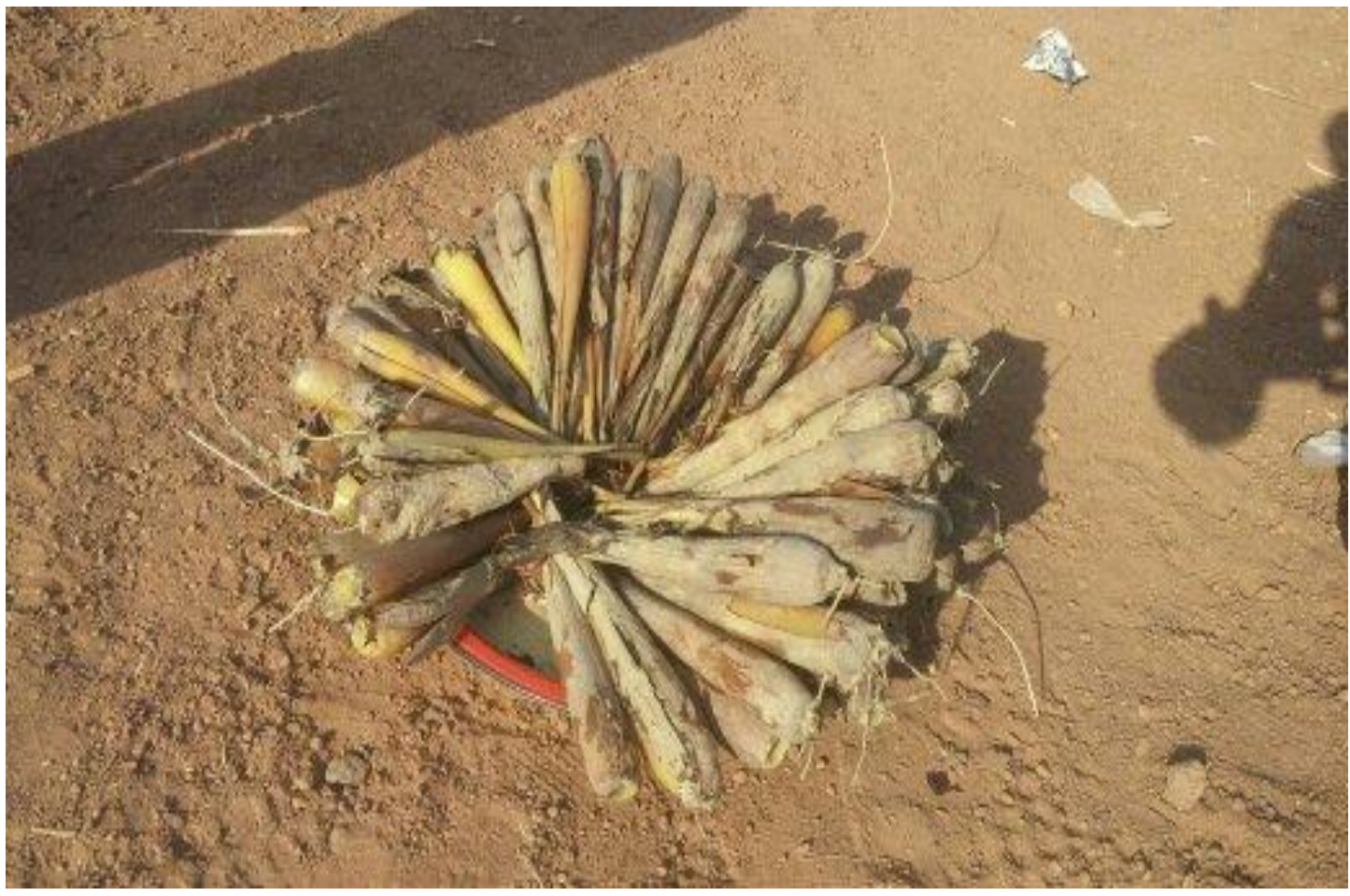

Fig.8 Wood (stems) of Borassus aethiopum Mart. for sale

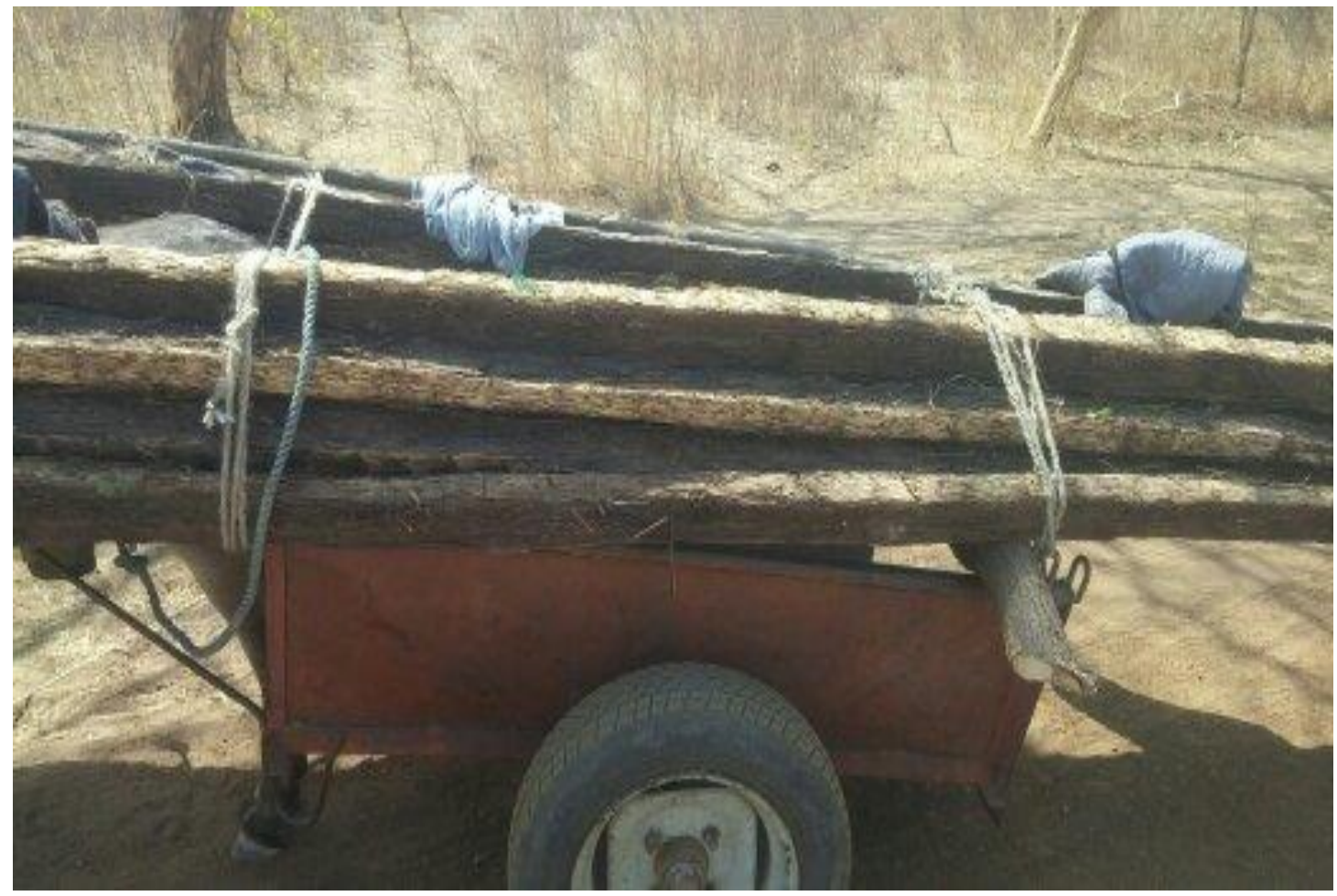


Table.1 The various known uses of the palmyra palm Borassus in the world

\begin{tabular}{|c|c|c|}
\hline Parts used & Domains & Products and uses \\
\hline Roots & Pharmacopoeia & $\begin{array}{l}\text { Antiasthmatic, diuretic, aphrodisiac, against the thinness and } \\
\text { the big stomach of children, sore throat, la bronchitis, } \\
\text { respiratory disorders, the extinction of voice. } \\
\text { The roots provide solid plant fibers used to make mats, ropes, } \\
\text { brushes, nets, etc. }\end{array}$ \\
\hline Hypocotyls & Food & Hypocotyls or seedlings eaten raw, boiled or scratched \\
\hline Stems & $\begin{array}{l}\text { Construction } \\
\text { Energy }\end{array}$ & $\begin{array}{l}\text { Building, sheds, floors, beams, rafters, benches, tables, bee } \\
\text { hives, ladders, canoes, gutters, troughs, bridges, etc. } \\
\text { Firewood }\end{array}$ \\
\hline Petioles & $\begin{array}{l}\text { Handicrafts } \\
\text { Fences } \\
\text { Pharmacopoeia } \\
\text { Energy }\end{array}$ & $\begin{array}{l}\text { Chairs, benches, stools, beds, suitcases, cradles, cages, ropes, } \\
\text { etc } \\
\text { Dead hedgerows, pens, cattle yards } \\
\text { Vermifuge } \\
\text { Firewood }\end{array}$ \\
\hline Limbo & $\begin{array}{l}\text { Handicrafts } \\
\text { Food } \\
\text { Fertilizer } \\
\text { Energy } \\
\text { Construction }\end{array}$ & $\begin{array}{l}\text { Making baskets, shelves, vans, mats, hats, bags, fans, cages, } \\
\text { aviaries, furniture, brooms, flutes, umbrellas, etc } \\
\text { Potash from the ashes. } \\
\text { Fertilization of soils. } \\
\text { Fuel } \\
\text { Covering huts and attics, Dead hedgerows, pens, cattle pens }\end{array}$ \\
\hline Fruits & Energy & $\begin{array}{l}\text { Fruits Food Energy Almond jelly of immature fruit edible. } \\
\text { Pulp of ripe edible fruit. Aromatic juice of the mesocarp used } \\
\text { in confectionery. Consumed by livestock (cattle, pigs) and } \\
\text { wild animals (elephants, monkeys). } \\
\text { Seedlings production. } \\
\text { The dried mesocarp is a good fuel }\end{array}$ \\
\hline Flowers & $\begin{array}{l}\text { Food } \\
\text { Pharmacopoeia }\end{array}$ & $\begin{array}{l}\text { The ash of the male flowers gives a good potash. } \\
\text { Inflorescences are used as fodder for livestock. } \\
\text { Extracts of male inflorescences: diuretic, antipyretic, } \\
\text { fortifying. The powder of male flowers mixed with shea } \\
\text { butter heals bedsores and edema. } \\
\text { The inflorescences help to fertilize the soil. } \\
\text { Male inflorescences: charcoal fuel after drying. }\end{array}$ \\
\hline Seeds & $\begin{array}{l}\text { Food } \\
\text { Handicrafts }\end{array}$ & $\begin{array}{l}\text { Contains a kind of edible jelly. } \\
\text { The shells of the seeds are used to make buttons, jewelry } \\
\text { boxes. Ash from nuts and used in dyeing. }\end{array}$ \\
\hline Sap & $\begin{array}{l}\text { Food } \\
\text { Pharmacopée }\end{array}$ & $\begin{array}{l}\text { Manufacture of palm wine, gin, vinegar and sugar. } \\
\text { Wine is considered a stimulant and aphrodisiac. }\end{array}$ \\
\hline Terminal bud & Food & $\begin{array}{l}\text { Bud of young shoots from } 3 \text { to } 4 \text { years produces an excellent } \\
\text { cabbage, very tender that one eats raw or cooked. Burned, the } \\
\text { ash of the bud is a good potash. }\end{array}$ \\
\hline Resin & Pharmacopoeia & A dark brown gum that acts as a medicine. \\
\hline
\end{tabular}

Sources: Portères, 1964; Giffard, 1967; Anonyme et Peltier, 1993; Yaméogo et al., 2008 
Table.2 Distribution of individuals surveyed in the study areas

\begin{tabular}{|l|l|c|}
\hline Region/Province & Villages & Number of individuals surveyed \\
\hline & Kompienbiga & 50 \\
Est / Kompienga & Kaboanga 1 & 50 \\
& Kaboanga 2 & 50 \\
\hline & Kamsé & 50 \\
\hline Centre-Est/ Koulpélogo & Soudougui & 50 \\
& Wango & 50 \\
\hline Total & 6 Villages & 300
\end{tabular}

Table.3 Distribution of individuals surveyed by sex

\begin{tabular}{|l|r|c|c|}
\hline \multicolumn{1}{|c|}{ Sex } & East region & Central-East region & Overall Percentage \\
\hline Man & $84(56 \%)$ & $82(54,7 \%)$ & 55,35 \\
\hline Woman & $66(44 \%)$ & $68(45,3 \%)$ & 44,65 \\
\hline Total & 150 & 150 & 300 \\
\hline
\end{tabular}

Table.4 Intensity of use of the palm parts by the populations of the East and Central-East

\begin{tabular}{|c|c|c|c|}
\hline Parts of palmyra & East Region & Central-Est Region & Overall Percentage \\
\hline & Effectif & Effectif & \\
\hline Fruits & $64(42,7 \%)$ & $117(78 \%)$ & 60 \\
\hline Leaves & $16(10,7 \%)$ & $11(7,3 \%)$ & 9 \\
\hline Stems & $6(4 \%)$ & $7(4,7 \%)$ & 5 \\
\hline Sap (Bandji) & $0(0 \%)$ & $0(0 \%)$ & 0 \\
\hline No use & $64(42,7 \%)$ & $15(10 \%)$ & 26 \\
\hline
\end{tabular}


Table.5 Summary of the main uses of palmyra by the populations of the East and Central-East

\begin{tabular}{ll}
\hline Parts of palmyra & Domain and mode of uses \\
\hline Leaves & Handicrafts (Mats, fans, chairs, baskets, aviaries, cages, hats) \\
& Fences (dead hedges, paddocks, livestock pens) \\
& Food (Ash spines to make potash and soap) \\
& Energy (Petiole as firewood) \\
Fruits & Food (Gummy almond of immature fruit and pulp of ripe fruit eaten by \\
& man and animals) \\
Seedling production (consumption or trade) \\
Construction (houses, sheds, bridges, poles, beams, floors, carpentry, \\
pillars, etc.) \\
Handicrafts (making furniture: benches, tables, stools, beds, etc.) \\
Wood (for trade)
\end{tabular}

The rural populations of the East and Central East recognize the socio-economic importance of Borassus aethiopum Mart. In Benin, Gbesso et al., (2013) also states that the palm is recognized and conserved within communities and ecosystems for not only its social importance (various uses, heritage of prestige and spiritual considerations), but also for its economic role (income and various benefits derived exploitation of the species by communities). In the eastern and centraleastern regions the populations use the different parts of the palm for their needs. Among the many uses offered by palm, it is the exploitation of the ripe fruits for the production of hypocotyls or seedlings which is the most practiced. The leaves and stems are also exploited for making many objects for construction and crafts. This form of exploitation of palm has been reported by several authors in other countries. According to Akinniyi et al., (2010) exploitation of the young shoots or hypocotyls of palmyra is only known in northern Nigeria where they are consumed raw or boiled as food and as an aphrodisiac. Hypocotyl is generally known to improve libido in women and has aphrodisiac properties in men and serves as a source of income for farmers (Balami et al., 2016). In the Abrimasu Forest Reserve of District in Ghana, 54\% of the populations use young shoots of Borassus aethiopum, they consume more of these young shoots than other parts. The sale of hypocotyls is the main activity because of its abundance, everyone has access and is sold outside the area (Siaw et al., 2014). Studies on the socio-economic importance of the palm in the commune of Savè in Benin have shown that the various organs consumed are fruits and hypocotyls. On the artisanal level, palm is weakly used in this commune. It is used for the manufacture 
of fans, hats, in the construction of houses, huts, attics, and showers. Medicinally, it is used to cure some diseases and especially sexual weakness. It is especially the production of hypocotyls that is valued at Savè (female activity, $87.93 \%$ ) (Gbesso et al., 2013, Gbesso et al., 2016). In Niger, fruits of Borassus aethiopum are eaten in the mature or immature state. The gelatinous albumen contained in the immature fruits, called "Kolodji" in the local language, is also consumed during field work against hunger and thirst. The pulp of ripe fruit is eaten raw and during the lean season, women use it to prepare the porridge. Hypocotyls or "miritchi" in the local language is well known to all populations for its important dietary contribution (Guimbo et al., 2012). The fruits of Borassus aethiopum Mart. are eaten as food and / or as a food supplement, especially during the famine period in northern Cameroon (Ali et al., 2010) and in Uganda (Oryema and Oryem-Origa, 2016). Yaméogo et al., (2016) reported that the palm Borassus akeassii is weakly exploited by populations in the central-west. The main uses are for leaves and fruits. Other parts of palm such as stem, inflorescences, roots and sap are most weakly exploited. The sap is not used for its food virtue but for a medicinal interest. The exploitation of palm sap is the main activity of the populations of western Burkina (Guinko and Ouedraogo, 2005; Yaméogo et al., 2008; Tapsoba et al., 2014). Borassus aethiopum is also exploited for its wine in Côte d'Ivoire and Senegal (Mollet et al., 2000). In India, various by-products of Borassus flabellifer such as palm sugar and gur (molasses) are also prepared from the juice extracted from the trunk. The immature nuts (Tal-Sans) and the Neera (wine) are very popular in the tropical regions of India as a natural carbonated drink to protect themselves from the summer heat (Chaurasiya et al., 2014). The inhabitants of Koulpélogo province and the kompienga don't know about the exploitation of the sap of palm for the wine production which is very widespread in western of Burkina. The different uses of palms vary according to the regions, it is better to know to exploit the tree to the maximum while managing it sustainably (Anonyme et Peltier, 1993). The exploitation of the young shoots (seedling) is linked to the abundance of palm, the simplicity of the technique of seedlings production and the ignorance of the other forms of exploitation. The populations don't know many modes of use of palmyra or are not interested in its uses. The under exploitation of palms could be explained by the fact that the populations of the East did not have very early considered its use. This has been reported by Guinko (1984) who affirmed that until the 1980s, palm stand did not always benefitted from respect in the exploitation of its products at East. In addition, the collection of rip fruits for the production of hypocotyls contributes to the degradation of the natural regeneration of the species. Actions for the conservation of Borassus aethiopum Mart. are very limited probably because Eastern populations still to consider as a wild tree still abundant and inexhaustible (Guinko and Ouédraogo, 2005).

The parts of the palm used by rural populations in the East and Central East are the leaves (9\%), the fruits (60\%) and the stipe $(5 \%)$. The production of seedlings from ripe fruits is the main form of exploitation and valorization of the species in the area, as is the exploitation of sap in the West. The inhabitants (100\%) are unaware the extraction technique of sap. Thus the sap of palm or Bandji is not exploited in this part of the country. In the same way, the numerous possibilities of uses in basketry that offer the leaves of palm are weakly exploited. Borassus aethiopum Mart. is under exploited in the Eastern and Central East and its current exploitation is not in favor of its conservation. A better knowledge of the different uses of 
palmyra by the local populations is necessary to better valorize the palms stands.

\section{References}

Aké Assi, L. et Guinko, S. 1996. Confusion de deux taxons spécifiques ou subspécifiques au sein du genre Borassus en Afrique de l'Ouest. In L.J.G. van der Maesen et al., (eds). The Biodiversity of African Plants: 773-779.

Akinniyi, J.A., Waziri, M. and Usman, HS. 2010. Assessment of the anabolic effect of androgens of the edible portion of the shoot of giginya plant (Borassus aethiopum Mart). J. Sci. Res. 2 (2): 362368.

Ali, A., Alhadji, D., Tchiegang, C. and Saidau, C. 2010. Physico-chemical properties of Palmyra Palm (Borassus aethiopum Mart.) fruits from northern Cameron. African J Food Sci. 4 (3):115-119.

Anonyme, et Peltier, R. 1993. Le rônier Borassus aethiopum Mart. (Palmées). Le Flamboyant. 27: 29-30.

Balami, A.A., Dauda, SM., Lawal, A. and Ahmad, D. 2016. Some engineering properties of Palmyra palm tree (Borassus aethiopum) germinating shoot. AgricEngInt: CIGR Journal. 18 (1): 58-69.

Bayton, R.P. and Ouédraogo, A. 2009. Discovering Africa's Newest Palm (Borassus akeassii). PALMS. 53 (1): 37-45.

Bayton, R.P., Ouédraogo, A. and Guinko, S. 2006. The genus Borassus (Arecaceae) in West Africa, with a description of a new species from Burkina Faso. Botanical Journal of the Linnean Society. 419-427.

Cabannes, Y., Chantry, G. et Willemin V. 1987. Le rônier et le palmier à sucre: production et mise en œuvre dans l'habitat. Dossier Technologie et
Développement, Ministère de la Coopération, Paris. $92 \mathrm{p}$.

Chaurasiya, A.K., Chakraborty, I. and Saha, J. 2014. Value addition of Palmyra palm and studies on the storage life. J. Food Sci. Technol. 51 (4): 768-773.

Gbesso, F., Adjatin, A., Dansi, A.A. and Akoegninou, A. 2016. Aphrodisiac Properties of Hypocotyls Extracts of Borassus aethiopum Mart (Arecaceae) Collected in Central of Benin Republic. Int. J. Curr. Microbiol. App. Sci. 5 (3): 802-814.

Gbesso, F., Akouehou, G., Tente, B. etAkoegninou, A. 2013. Aspects technico-économiques de la transformation de Borassus aethiopum Mart (arecaceae) au Centre-Bénin. Afrique SCIENCE. 09 (1): 159-173.

Giffard, PL. 1967. Le Palmier rônier Borassus aethiopum Mart. In Revue Bois et Forêts des Tropiques. $\mathrm{N}^{\circ} 116$.

Guimbo, ID., Barrage, M. et Douma, S. 2012. Etudes préliminaires sur l'utilisation alimentaire des plantes spontanées dans les zones périphériques du parc $\mathrm{W}$ du Niger. Int. J. Biol. Chem. Sci. 6 (6): 4007-4017.

Guinko, S. 1984. Végétation de la Haute Volta. Thèse de Doctorat d'État. Tome 1. Université de Bordeaux III, France, $318 \mathrm{p}$.

Guinko, S. et Ouédraogo, A. 2005. Usages et enjeux de conservation du rônier (Borassus L.) à l'Est et à l'Ouest du Burkina Faso. In: Boussim I.J., Lykke A.M., Nombré I., Nielsen I. \& Guinko S. (Eds). Homme, plantes et environnement au Sahel occidental. Serein Occasional Paper $\mathrm{N}^{\circ}$ 19. pp. 1-6.

Mollet, M., Herzog, F., Behi, Y.E.N. and Farah, Z.2000. Sustainable exploitation of Borassus aethiopum, Elaeisguineensis and Raphiahookeri for the extraction of palm wine in Cote 
d'Ivoire. Environ Dev Sustain. 2: 4559.

Oryema, C. and Oryem-Origa, H. 2016. Analysis of the Fresh Pulps of Borassus aethiopum Fruits of Gulu District, Uganda. American Journal of Food and Nutrition. 4 (6): 177-181.

Ouédraogo, A. 1999. Biomorphologie des rôniers (Borassus L.) du Burkina Faso. Mémoire de DEA, Université de Ouagadougou. Ouagadougou. 69 p.

Ouédraogo, A., Boussim, J., Zongo, J. etGuinko, S. 2002. Caractéristiques morphologiques des rôniers (Borassus L.) du Burkina Faso. Études sur la Flore et la Végétation du Burkina Faso et des pays avoisinants 7: 37-40.

Ouoba, LII, Kando, C., Parkouda, C., Sawadogo-Lingani, H., Diawara, B. and Sutherland, JP. 2012. The microbiology of Bandji, palm wine of Borassus akeassii from Burkina Faso: identification and genotypic diversity of yeasts, lactic acid and acetic acid bacteria. Journal of Applied Microbiology. 113: 1428-1441.

Portères, R. 1964. Le palmier rônier (Borassus aethiopum Mart.) dans la Province du Baoulé (Côte d'Ivoire). In: Journal d'agriculture tropicale et de botanique appliquée. 11 (12): 499-514.
Siaw, DEKA., Asamoah, E.F. and Baidoe, GA. 2014. The stock and socioeconomic uses of Borassus aethiopum in Abrimasu Forest Reserve of Mampong Forest District. JENRM. 1 (3): 148-155.

Tapsoba, F., Savadogo, A., Zongo, C. and Traoré, AS. 2014. Impact of technological diagram on biochemical and microbiological quality of Borassus akeassii wine produced traditionally in Burkina Faso. American Journal of Food Science and Technology. 2 (6): 179-186.

Yaméogo, J., Bélem-Ouédraogo, M., Bayala, J., Ouédraogo, MB. And Guinko, S. 2008. Uses and commercialization of Borassus akeassii Bayton, Ouédraogo, Guinko non-wood timber products in South-Western Burkina Faso, West Africa. Biotechnologie, agronomie, sociétéet environnement. 12 (1): 47-55.

Yaméogo, J., Samandoulgou, Y. et Belem, M. 2016. Le rônier (Borassus akeassii B.O.G.) dans les parcs agroforestiers à Kokologho, Sakoinsé et Ramongo dans la province du Boulkiemdé, Centreouest du Burkina Faso. Journal of Applied Biosciences. 100: 9557 - 9566.

\section{How to cite this article:}

Oumarou Zongo, François Tapsoba, Hama Cisse, Yves Traore and Aly Savadogo. 2018. Modes of Use of the Palm Borassus aethiopum Mart. by the Rural Populations of Eastern and CentralEastern Regions from Burkina Faso. Int.J.Curr.Microbiol.App.Sci. 7(12): 62-74. doi: https://doi.org/10.20546/ijcmas.2018.712.009 